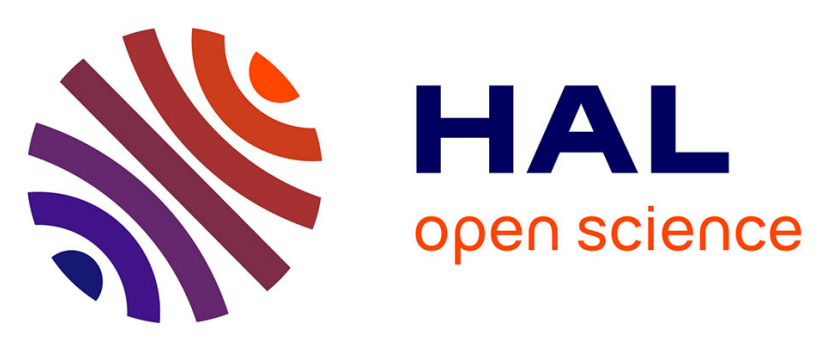

\title{
Processing Time and Cognitive Effort of Longhand Note Taking When Reading and Summarizing a Structured or Linear Text
}

Thierry Olive, Marie-Laure Barbier

\section{To cite this version:}

Thierry Olive, Marie-Laure Barbier. Processing Time and Cognitive Effort of Longhand Note Taking When Reading and Summarizing a Structured or Linear Text. Written Communication, 2017, 34 (2), pp.224 - 246. 10.1177/0741088317699898 . hal-01771727

\section{HAL Id: hal-01771727 \\ https://hal.science/hal-01771727}

Submitted on 11 May 2018

HAL is a multi-disciplinary open access archive for the deposit and dissemination of scientific research documents, whether they are published or not. The documents may come from teaching and research institutions in France or abroad, or from public or private research centers.
L'archive ouverte pluridisciplinaire HAL, est destinée au dépôt et à la diffusion de documents scientifiques de niveau recherche, publiés ou non, émanant des établissements d'enseignement et de recherche français ou étrangers, des laboratoires publics ou privés. 


\section{Processing time and cognitive effort of longhand note taking when reading and summarizing a structured or linear text}

Thierry OLIVE

Centre National de la Recherche Scientifique \& Université de Poitiers

and

Marie-Laure BARBIER

Centre for Research on the Psychology of Cognition, Language and Emotion \& Aix-Marseille Université

Author notes

Thierry Olive is a researcher at the National Centre for Scientific Research (CNRS),

France. He conducts his research at the Centre for Research on Cognition and Learning, a joint research unit of the CNRS and of the University of Poitiers, France. Marie-Laure Barbier is Associate Professor at Aix-Marseille University, France, and a member of the Centre for Research on the Psychology of Cognition, Language and Emotion.

Correspondence concerning this article should be addressed to Thierry Olive, Centre de Recherches sur la Cognition et l'Apprentissage, Université de Poitiers \& CNRS, 5 avenue Théodore Lefebvre, TSA 21103, 86073 Poitiers Cedex 9, France. Phone: +33 549366299. Fax: +33 5494546 16. E-mail: thierry.olive@ univ-poitiers.fr. 


\title{
Processing time and cognitive effort of longhand note taking when reading and summarizing a structured or linear text
}

\begin{abstract}
We examined longhand note taking strategies when reading and summarizing a source text that was formatted with bullets or that was presented in a single paragraph. We analyzed cognitive effort when reading the source text, when jotting notes, when reading the notes, and when composing the summary, as well as the time they spent in these activities and the content of the notes and the summaries. With a formatted text, students' perceived comprehension difficulty was lower, they expended less cognitive effort, spent less time reading the text, and noted more ideas. While composing the summary, only those students who read the formatted source text continued selecting ideas in their notes. Finally, the summaries were unaffected by the formatting of the source text. The study shows that formatting a source text with bullets facilitates note taking by helping students to grasp its structure and by reducing the cognitive effort of reading.
\end{abstract}

Keywords: note taking, text formatting, signaling devices, summarizing, cognitive effort. 


\section{Introduction}

Note taking occurs frequently in academic learning and in professional activities. Notes can be taken from a lecture or from a written document. During a lecture, note taking is generally realized under severe time pressure, since noting is slower than speaking (although specific techniques such as stenography, abbreviations, etc., can be used to note faster). By contrast, when taking notes from a written document, note takers can complete their activity at their own pace. Notes can be written with paper and pencil or with the keyboard of a computer (or of a tablet). Taking notes with paper and pencil favors more synthetic and structured notes, and note takers remember more inferential and conceptual content of the source material. With computers, notes are more linear, more verbatim, and note takers remember more factual information (Mueller \& Oppenheimer, 2014). It is important to underline that note taking should not be considered as mere verbatim recording of information: Note takers, like readers, must comprehend the source information, and like writers, they usually create new text by reformulating and synthesizing information they have selected (for a detailed analysis, see Piolat, Olive \& Kellogg, 2005). Note taking is, therefore, a highly complex activity that intertwines comprehension of discourse and production of written language, and which engages several central cognitive operations, such as integration, inference, planning and assessment. In the present study, we focused on note taking from a written source when it is realized with paper and pencil. By manipulating encoding of information through the visual spatial organization of a source text with different formatting, we investigated how individuals encode and note information for writing a synthesis. We analyzed the note taking strategy, cognitive load, and quality of the notes as well as the synthesis that were produced afterward. 
Extensive research in educational psychology has shown that note taking is a powerful tool for synthesizing, memorizing, and reviewing information. It particularly fosters knowledge integration by helping note takers to structure the content and to integrate it in a way that facilitates understanding and reviewing (Baker \& Lombardi, 1985; Kiewra, Benton, \& Lewis, 1987; King, 1992; Kobayashi, 2006; Nye, Crooks, Powley, \& Tripp, 1984; Williams \& Eggert, 2002). The benefits of note taking stem from two functions: external storage and encoding of information (Benton, Kiewra, Whitfil, \& Dennison, 1993). Notes, indeed, constitute an external form of memory for note takers, who do not need to memorize a whole lecture or reading, and who can review their notes long after the note taking has occurred. Of major importance for the purpose of this study, taking notes promotes encoding in long-term memory, as it requires selection and organization of information. Among the variables that moderate encoding of information, visual spatial organization of information, i.e. text formatting, is influential since it affects quality of the notes (for a meta-analysis, see Kobayashi, 2005).

A wide variety of graphical signs can be used to format a text: discursive information may be used to highlight particular points (e.g., "It is important to note that..."), as key-words and headings add linguistic information to the text by indicating the main topics to readers. There are also extra linguistic signals, such as paragraphing, indentation, list effects, line breaks, and typographical signals, such as boldface or italics, which spatially distribute the text across the space of the page and highlight specific information in the text.

By providing extra information about the content and structure of a text, formatting a source text with such signals might be expected to affect readers' memory and mental model of the read text. This is confirmed by research on text comprehension that has established that signaling devices influence readers' recall and comprehension in adults (Lorch \& Lorch, 1995; 
Meyer, 1985; Meyer \& Poon, 2001), typical children (Gajria, Jitendra, Sood, \& Sacks, 2007), and children with learning difficulties (DiCecco \& Gleason, 2002; Kim, Vaughn, Wanzek, \& Wei, 2004). By directing readers' attention to relevant information, organizational signals influence how that information is perceived and processed in memory. More specifically, signaling devices do not affect how much readers will recall, but what they will recall (Schmid \& Baccino, 2002). When signals are absent from a text, readers encode the text as a temporally organized (i.e., linear) list of ideas. At recall, the list representation is searched serially, with the recall of one idea cueing the next item in the list. By contrast, the inclusion of organizational signals induces a hierarchical mental representation of the text's structure that is encoded during reading of the document (Lorch \& Lorch, 1995).

In parallel, research in educational psychology has also confirmed that organizational signals positively influence memorization of information when taking notes. For example, in college students, learning just after a lecture is better when the lecture contains organizational cues, and delayed retention is improved when students take notes from lectures containing such cues (Titsworth, 2001), especially when these take the form of graphic organizers (e.g., matrices, diagrams, concept maps), rather than outlines (Katayama \& Robinson, 2000; Robinson, Katayama, Dubois, \& Devaney, 1998). Outlines represent the text's concepts and subordinate concepts, listing their attribute values in a linear format. By contrast, graphic organizers visually and explicitly depict the different relationships between the concepts contained in the text. As such, they are assumed to increase computational efficiency (Robinson \& Kiewra, 1995).

The influence of signaling devices on the cognitive processing of texts can be interpreted within the framework of Mayer's (1996) Selection, Organization, and Integration (SOI) model 
of learning. Meaningful learning occurs when learners select relevant material, organize that material into a coherent structure in their working memory, and integrate it with prior knowledge from their long-term memory. Thus, organizational signals are primarily expected to influence the selection and organization of information as described in the Signaling Available Relevant Accessible (SARA) information theory of text signaling devices (Lemarié, Lorch, Eyrolle, \& Virbel, 2008). This theory posits that signals are processing instructions that influence how readers process a text by affecting the availability, relevance, and accessibility of the signaled content. Accordingly, an analysis of the signals used in a particular text should not only describe the information function of the signals, but also how the signaled information affects note takers' processing by reducing cognitive load associated with reading and selecting the information.

Since note taking is a writing task (see earlier), research on writing may also inform research on note taking. For example, studies on how texts are designed (Schriver, 1996) or on how visual spatial processing intervenes during writing may contribute to better understanding of note taking and of the role of signaling devices. Indeed, although writing is clearly a linguistic activity, it is also a visual activity, guided by the writer's eyes, and a spatial activity in that it involves organizing the text by leaving a graphic trace on the page and by organizing it according to the semantic structure of the text (Olive \& Passerault, 2012). Of particular importance, Haas and Hayes (1986) proposed that constituting an overall visual-spatial representation of a text helps writers to elaborate a global sense of it. In this perspective, organizational signals may contribute to construction of a visual-spatial mental representation of the produced text by facilitating encoding of the source text in visual spatial working memory (Hayes, 1996; Kellogg, 1996; Olive, 2004, 2012). Graphic organizers contribute to this 
elaboration by intervening in the specific layout of each text and by making the visual-spatial representation of a text is distinctively encoded in long-term memory. A more distinctive trace of the text in memory may, in turn, helps writers to find and retrieve information in the text when it is needed (for a review, see Le Bigot, Passerault, \& Olive, 2010). Accordingly, from a visual-spatial perspective, graphic organizers may also benefit note takers by reducing the cognitive load associated with writing the notes and even with composing a text from these notes afterward.

In sum, several research fields contribute to research on note taking and to research on the role of organizational signals. Studies in educational psychology have confirmed that organizational signals mediate the positive effect of note taking. Studies on text comprehension have demonstrated that organizational signals impact encoding of information by helping readers to construct a hierarchical mental model of the read text. Research on writing has shown that note taking is not simple transcription of a heard or read discourse, but rather comprehending and composing a new one. In addition, research on visual spatial working memory in writing suggests that note takers should benefit from the visual spatial characteristics of the source text when using the notes. From this perspective, the present experiment investigated how the formatting of a source document influences longhand note taking strategy in terms of distribution of time and of cognitive effort involved in reading, note taking, and composing a summary from the notes taken. Note taking from a written document is a highly demanding task, as it intertwines text comprehension and writing for constructing the mental model of the source text, selecting and noting appropriate information. Research on comprehension has provided strong evidence that knowledge integration and inferential processes are resource consuming (Just \& Carpenter, 1992). In addition, a writer's cognitive 
effort is much higher during note taking than during text composing (Piolat, Olive, \& Kellogg, 2005), suggesting that writing during note taking is more than mere transcription and is closed to writing during text composition. Examining the effects of the formatting of a source text on participants' cognitive effort would, therefore, provide insights in how the formatting of source texts affects reading, noting and composing processes.

Cognitive effort was assessed with a secondary reaction time task. Participants were asked to read and to take longhand notes from a source document that was either unformatted (the text was displayed as a single paragraph) or formatted with bullets and indentations that spatially represented first- and second-order topics (see Appendix 1). Afterwards, they were asked to compose a summary of this document, relying entirely on their notes. During these two successive tasks, participants had to press a button as soon as they heard a beep. After each response, they indicated which activity they were engaged in (reading the source document or writing down the notes at first, and reading the notes or writing the text afterward) by pressing a key on a keyboard. This allowed us to analyze the cognitive effort participants devoted to each of these activities, in either taking the notes or composing the summary (for a review of the method, see Piolat, Olive, Roussey, Thunin, \& Ziegler, 1999). Cognitive effort was defined as the amount of cognitive resources needed for note takers to perform the two tasks. It was measured by length of reaction times (RT). We also analyzed the time spent on each activity in either taking the notes or composing the summary, as well as the structure of the notes and similarity between the source text and the summaries produced.

If signaling devices do increase computational efficiency (or facilitate the selection and integration of relevant information), then a text formatted with signals indicating the hierarchical structure of the text should facilitate note taking and summarizing. Accordingly, we 
predicted that the time and cognitive effort spent jotting down the notes, as well as reading the notes and composing the summary should be reduced when note takers worked from the formatted source document. In addition, the notes would be structured according to the formatting of the source text.

\section{Method}

\subsection{Participants}

Fifty undergraduate volunteers (mean age $=21.9$ years) took part in the experiment. They were randomly assigned in equal numbers to the unformatted and formatted conditions. All participants were native French speakers and were tested individually in accordance with the APA and University of Poitiers ethical standards and guidelines. All students gave their informed consent before participating in the experiment.

\subsection{Material}

The source text from which the participants took notes described how a fictive bus pass works. It described the rules that govern the use of the card, how to use it, and how to reload it. This text had a two-level structure, with seven first-order points, and sixteen second-order ones. Both versions of the text fitted onto a single page. The unformatted text contained 666 words, while the formatted one contained 689 words. This difference resulted from necessary modifications to adapt some of the sentences to the formatting. Both versions are provided in Appendix 1.

\subsection{Tasks}

Note taking task. Participants had 15 minutes to take notes, with a paper and a pencil, from the source text. They had to spend all 15 minutes taking notes. They were given the following instructions: "The text you are going to read contains information about how to use a 
pass to travel on buses in the city. You have 15 minutes to understand how to use this pass and to take notes from this text." No specific instructions were given as to how to take the notes but writers were instructed that they took notes for writing a summary. Thus, participants were free to use the note-taking strategies they currently used. We analyzed the occurrences of text reading and noting activities. The participant's cognitive effort allocated to each of these activities was measured with the reaction time task, the number of ideas they selected in the text, and the number of notes structured in two levels, as in the text.

Summarizing task. After the participants had finished taking their notes, they had 15 minutes to compose a summary of the source text. During this time, they only had access to their notes (and not to the source text). They had to write a well-structured summary with no abbreviations and using full sentences. We analyzed the occurrences of note reading and composing activities, the participant's cognitive effort allocated to each of these activities, the number of ideas they included in their summaries, and the number of ideas suppressed (noted but not appearing in the summary). Finally, we assessed the degree of similarity between each summary and the source text by using a latent semantic analysis (LSA) (Landauer, Foltz, \& Laham, 1998).

Reaction time task. While they were realizing both tasks, participants had to respond as quickly as possible to auditory probes by pressing a button they kept in their non-dominant hand during the experiment. After each response, they had to press a key on their keyboard to indicate whether they were engaged in reading the text or noting ideas during the note-taking task, and whether they were engaged in reading their notes or composing during the summarizing task. Accordingly, each RT was associated with the activity the participant indicated when the probe occurred. 
Cognitive effort was calculated by subtracting the participants' mean baseline RTs from each of the secondary RTs. To obtain these baselines, the RT task was first performed in a single-task situation. As in previous studies that used this method (see Olive, Kellogg, \& Piolat, 2002), auditory probes were played once every 10 seconds on average (range 5-15 s) in the baseline RT task, and once every 30 seconds on average (range 15-45 s) during the secondary RT task. This secondary RT task has been shown to be nonintrusive: it does not interfere with the quality of the text produced while responding to the probes, nor does it affect how the writing processes are engaged in the course of writing. A modified version of ScriptKell (Piolat et al., 1999) was used to display the text, randomly distribute the auditory probes, and record the participants' RTs and activities. Finally, the number of probes in each activity indicated how many episodes of these activities occurred.

Assessing comprehension of the source text. Participants' subjective feeling of comprehension of the source text was also assessed. They were asked to subjectively rate their comprehension with a seven-point Likert-like scale ranging from 1 (Easy) to 7 (Difficult to understand).

\subsection{Procedure}

Participants began the experiment by completing the baseline RT task. Second, they took notes from the source text. While taking notes, they responded to auditory probes and indicated the activity they were engaged in when the probe occurred. Third, they summarized the source text based solely on the notes they had taken during the note-taking phase (the source text was not available anymore). During this phase, they continued to respond to auditory probes and to indicate the activity they were engaged in when they heard the probes. Finally, participants rated their subjective feeling of comprehension of the source document. 


\section{Results}

\subsection{Comprehension of the source document}

Participants' feeling of comprehension of the source document was assessed with a seven-point scale: the lower the score, the better their subjective feeling of comprehension. An independent $t$-test indicated that participants' ratings of comprehension were significantly lower for the formatted source text $(M=2.44, S D=0.590)$ than for the unformatted one $(M=3.04, S D$ $=1.04), t(48)=2.35, p=.023, d=0.66$. Therefore, participants had the feeling that they better understood the formatted text.

\subsection{Note-taking Task}

Cognitive effort for reading and noting. A $2 \times 2$ analysis of variance (ANOVA) with formatting (unformatted, formatted) as a between-participants factor and activity (reading, noting) as a within-participant factor was run on the mean interference RTs (mean baseline RT subtracted from the secondary RTs). The mean and standard errors are plotted in Figure 1. A significant main effect of formatting was observed, $F(1,48)=7.40, p=.009, \eta_{\mathrm{p}}^{2}=.13$. Participants expended more cognitive effort $(M=302 \mathrm{~ms}, S D=79 \mathrm{~ms})$ with the unformatted text than with the formatted one $(M=253 \mathrm{~ms}, S D=61 \mathrm{~ms})$. Activity also significantly affected cognitive effort, $F(1,48)=6.81, p=.01, \eta_{\mathrm{p}}^{2}=.12$. Participants expended less cognitive effort when they read the source text $(M=266 \mathrm{~ms}, S D=70 \mathrm{~ms})$ than when they jotted down notes $(M$ $=290 \mathrm{~ms}, S D=69 \mathrm{~ms})$. The Formatting x Activity interaction was not significant, $F(1,48)=$ $2.48, p=.12, \eta_{\mathrm{p}}^{2}=.05$. Across conditions, participants expended less cognitive effort when they read the text than when they noted down their ideas. They also devoted less cognitive effort to reading and to noting ideas when they worked with the formatted document than the unformatted one. 
Processing time and cognitive effort of longhand note taking 13

Insert Figure 1 here

Occurrences of text reading and noting activities. A 2 x 2 ANOVA with formatting (unformatted, formatted) as a between-subjects factor and activity (reading, noting) as a withinsubject factor was run on the mean number of times participants indicated they were engaged in reading the text or noting down ideas. The means are plotted in Figure 2.

There was no main effect of formatting, $F<1$, but a significant main effect of activity was found, $F(1,48)=6.331, p=.015, \eta_{\mathrm{p}}^{2}=.12$. Across conditions of formatting, participants indicated fewer reading activities $(M=9.6, S D=3.1)$ than note taking activities $(M=11.5, S D$ $=4.1)$. This effect interacted with the document formatting, $F(1,48)=9.08, p=.004, \eta_{\mathrm{p}}^{2}=.16$. Scheffé's post hoc tests indicated that students only indicated fewer reading activities $(M=8.4$, $S D=3.4)$ than note taking ones $(M=12.4, S D=4.4)$ with the formatted source document. With the unformatted text, participants pointed out roughly the same number of reading and note taking activities. As a consequence, with the formatted text, they identified less reading than with the unformatted one $(M=10.8, S D=2.1)$. In summary, the formatted document involved less reading, which, in turn, provided note takers with more time to work on their notes.

Insert Figure 2 here

Number of ideas in the notes. A Student $t$-test was conducted on the total number of ideas present in the notes according to the formatting of the text (maximum number of ideas $=$ 23). Table 1 shows means and standard deviations for each condition. The analysis indicated 
that the number of ideas was significantly higher in the formatted source text than in the unformatted version of the source text, $t(48)=3.45, p<.001, d=.98$. Accordingly, the formatted text led participants to record more ideas.

Insert Table 1 here

Structure of the notes. A Fisher's exact test, carried out on the number of participants who structured their notes in two levels, was significant, $p<.001$. Notes with a two-level hierarchy were more frequent with the formatted text $(92 \%, 23 / 25)$ than with the unformatted one $(48 \%, 12 / 25)$.

\subsection{Summarizing task}

Cognitive effort for reading and composing. A 2 × 2 ANOVA was carried out on the mean interference RTs with formatting (unformatted, formatted) as a between-participants factor and with activity (reading, composing) as a within-participants factor (see Figure 3). Activity had a significant main effect, $F(1,48)=15.12, p<.001$, partial $\eta^{2}=.24$. Participants' cognitive effort was lower when reading $(M=289 \mathrm{~ms}, S D=88 \mathrm{~ms})$ than when composing the summary $(M=329 \mathrm{~ms}, S D=87 \mathrm{~ms})$. Neither the effect of formatting nor the interaction was significant $\left(F_{\mathrm{s}}<1\right)$, indicating that cognitive effort when composing the summary was not affected by the formatting of the source document.

Insert Figure 3 here 
Occurrences of notes reading and composing activities. A similar 2 x 2 ANOVA was carried out on the mean number of times participants indicated they were engaged in reading their notes or composing the summary (see Figure 4). This analysis revealed a significant main effect of the activity, $F(1,48)=218.9, p<.0001, \eta_{\mathrm{p}}^{2}=.82$. When summarizing, participants indicated more composing activities $(M=20.0, S D=0.5)$ than reading ones $(M=6.8, S D=$ 0.5). The effect of formatting and its interaction with activity failed to reach significance $(F \mathrm{~s}<$ 1). Thus, participants needed more time for composing their summaries than for reading their notes, regardless of the source text's formatting.

\section{Insert Figure 4 here}

Number of ideas in the summaries. We conducted a Student $t$-tests on the number of ideas present in the summaries (see means and standard deviations in Table 1). Formatting did not reliably affect the number of ideas present in the summaries, $t(48)=1.014, p=.32$, indicating that the number of ideas that participants included in their summaries was not affected by the formatting of the source document.

Number of suppressed ideas. Another Student $t$-tests was conducted on the number of ideas that participants noted without including them in their summary (ideas in summaries ideas in notes). Means and standard deviations are indicated in Table 1. A significant effect of formatting was observed on the number of suppressed ideas, $t(48)=-4.124, p<.001, d=.98$. In fact, twice as many ideas in the notes taken from the formatted source were not retained in the summaries, compared with notes taken from the unformatted text. 
Processing time and cognitive effort of longhand note taking 16

Similarity of the summaries to the source document. To examine the similarity of the summaries to the source document, we used the LSA website (lsa.colororado.edu) and conducted a one-to-many and document-to-document latent semantic analysis. A Student's $t$ test indicated that the similarity to the source document for summaries of the formatted document $(M=0.78, S D=0.11)$ did not differ significantly from that for summaries of the unformatted one $(M=0.79, S D=0.12), t(48)=0.307, p=.76$. Regardless of the formatting of the source document, the summaries did not differ in terms of semantic content, at least as assessed with Latent Semantic Analysis.

\section{Discussion}

Several studies have shown that signaling devices have positive effects on reading and text production activities. In the present experiment, we investigated how text formatting affects longhand note taking strategies, by examining participants' cognitive effort, and the occurrences of the activities involved in note taking and summarizing, as well the quality of the notes and the summaries effectively produced.

First, regardless of the formatting of the source text, participants expended more cognitive effort when they jotted down their notes than when they read the source document. It has however to be noticed that the size of this effect is medium and therefore would require further replication with larger power. This finding replicates previous analyses of note takers' cognitive effort, showing that note taking is at least as demanding as writing a text and more so than reading, presumably because the processes involved in note taking are similar to those used to compose a text (Piolat, Olive, \& Kellogg, 2005). In fact, selecting, organizing, and synthesizing information may be supported by the planning process, whose function is to retrieve and organize conceptual knowledge about the written topic. Moreover, when note takers 
reformulate information in their notes, they rely on the writing process of translating. Finally, reading the notes in order to assess their relevance is likely to involve the revising writing process. Therefore, in the present study, the cognitive effort while taking notes from the unformatted document was comparable to the cognitive effort while composing (with a mean interference reaction time of $325 \mathrm{~ms}$ ). Since writing is a particularly effortful cognitive activity (Kellogg, Whiteford, Turner, Cahill, \& Mertens, 2013; Olive, 2014), and is more effortful than reading, it is not surprising that the note takers expended greater cognitive effort when jotting down ideas than when reading. This also suggests that notetaking from a written text is distinguishable from the verbatim recording of information during a lecture, which is constrained by the lecturer's pace of delivery. With a written document, note takers have sufficient time to structure, reformulate or review their notes, just as they would when they compose a text. The second finding concerns the effect of formatting during the note-taking task. The formatted source text first reduced students' cognitive effort across the whole task, as the mean reaction times were lower for reading than for noting selected ideas (again with a medium power). Interestingly, the absence of interaction suggests that formatting had no specific effect on either reading or writing, although it could be expected that to affect reading of the source text more than noting ideas. Because of the low power of the interaction and the size of the sample, the present findings on cognitive effort deserve to be replicated with a larger sample of students.

Second, formatting also affected how students shared their time between reading the source text and noting ideas. The occurrences of reading activities were significantly lower than noting ones, whereas, in the unformatted condition, students shared their time equally between reading and noting activities. Consequently, they had more time to jot their notes, and, probably, 
to structure the information in their notes, reformulating ideas, as well as reviewing what they had noted. In the formatted condition, they also regulated their cognitive effort for jotting notes, as their mean reaction time to the secondary task was significantly reduced ( $\mathrm{M}=260 \mathrm{~ms})$ compared to the unformatted condition $(M=324 \mathrm{~ms})$. Taken all together, these results support the idea that documents featuring signals to highlight the text structure mainly impact on note taking by facilitating reading. This is consistent with the student's feeling of comprehension and the lower difficulty participants perceived when processing the formatted document in contrast with the unformatted one. In this study, as in a previous one (Barbier, Roussey, Piolat, \& Olive, 2006), the student's feeling of comprehension is closely linked with cognitive overload and strategies used for note taking. As such, facilitating comprehension helps note takers to manage the whole of their cognitive effort and processes during note taking.

By facilitating the regulation of note taking, the formatting of the document also affected both the quantity and quality of the notes. In the formatted condition, students noted more ideas, despite spending less time on reading, with less cognitive effort. This, again, supports the idea that formatting a text benefits note takers by facilitating comprehension during the reading activity and, therefore, storing information during note taking. In addition, more than $90 \%$ of the notes were structured in two levels (as was the source document, see Appendix 1), whereas fewer than $50 \%$ of them were structured in two levels in the unformatted condition. Thus, the notes closely mirrored the structure of the source document, which contained two explicit levels of hierarchy highlighted by specific text signaling devices in the formatted version. In other words, the structure of the source text guided the structuring of the notes. 
By contrast, the formatting effect had little impact on the summarizing task. Given that readers benefitted from the formatted text to store and encode the underline hierarchical structure, we expected such structure to influence composition of the summary In fact, formatting of the source text had little impact on how writers proceed during the summarizing task. Although writers expended greater time and cognitive effort when composing the summary than when consulting their notes, confirming again that writing is more effortful than reading (Piolat, Olive, \& Kellogg, 2005), formatting did not affect either the cognitive effort or the occurrences of episodes of reading and composing. Writers did not change how they allocated their attention and time to read their notes and compose the summary.

Formatting, however, impacted how writers inserted their notes in their summary. Although they contained roughly the same number of ideas in both conditions (13), writers inserted around $60 \%$ of the ideas they had noted with the formatted text, and around $80 \%$ of their notes with the unformatted text. Therefore, when summarizing, writers who took notes from the formatted text still continued to select information during the composition task. As they had no access to the source text, they probably relied on their memorization and comprehension of the source text to achieve this selection. In comparison, participants who read the unformatted document selected more information during the first task and relied only on their notes to compose their summaries. This also occurred in a study by Barbier, Piolat, Roussey, and Raby (2008), where participants had at first to take notes from a website, by handwriting or typing, and second to compose a summary from their notes. Although writers' cognitive effort associated with note taking was lower in the typing condition (because they copied and pasted text in the source material rather than formulating their own notes), they did not select as many ideas as in the handwriting condition, and they still selected them while 
Processing time and cognitive effort of longhand note taking 20

composing the summary. As in Barbier et al.'s study, with reduced cost of reading associated with the formatted text, writers in the present experiment continued to select ideas during the summary task, whereas the unformatted text made writers noting fewer ideas and relying more on their notes. In addition, similarity between the source text and the final summaries did not differ according to the text formatting. Although participants took different notes with a formatted document, their final summaries were not closer to the source document than those produced by participants who consulted the unformatted document.

How to explain this absence of effects of formatting on composition of the summary, despite effects on note taking suggesting that the writers hierarchically encoded the text after they read the formatted version? First, it has to be mentioned that a majority of studies assessed the effects of formatting with recall tasks, which strongly differ from summarizing. Whereas recalling requires mainly to access information stored in long-term memory, summarizing involves knowledge integration, reformulation, and restructuring. It is therefore difficult to compare the effect on formatting with previous studies that reported positive effects of formatting on recall tasks. This absence of effect on the summary may come from the type of text that was read and had to be summarized. The source text is a procedural text which describes actions. It is very factual and does not require high inferential processes. Therefore, it is likely that notes' content in both conditions was sufficient to summarize the main points of the source text. More conceptually driven text would presumably reveal effects of formatting during the summarizing phase as it would require more knowledge integration.

\section{Conclusion}

In summary, the formatted source facilitated note taking by reducing participants' cognitive effort associated with reading the source document, and by reducing the time they 
allotted to reading. These benefits resulted both from the semantic information that graphic organizers add to the text, and from a specific physical layout which contributed to a better visual-spatial mental representation of the text. As a consequence of this facilitation in reading, noters took more time for noting, with less cognitive effort. They noted more ideas, following the structuration of the source document, and they continued to work on the information by selecting and suppressing ideas during the summarizing task.

These findings may have implications for designers and computer scientists in academia and industry who are concerned in document design. Especially as more laptops and tablets infiltrate the classroom and the office, the implication of formatting should be studied further, to better understand how it affects reading and the associated writing activities. Is the facilitation of reading with formatting really an advantage for writing activities as a whole? Designing documents that clearly help students to mentally represent the structure of the source material has also educational implications as it may foster how students select and integrate information they read. This may help them, as writers, to plan and prepare drafts, what Haas (1990) calls note-making. Finally, because note taking from computers tend to create more verbatim notes and more memorization of factual ideas (Muller \& Oppenheimer, 2014), formatting may also be used to enhance synthetic note taking by students who prefer to use their computers.

To conclude, it has to be noticed that generalization of the findings is limited to the type of formatting we used (i.e., bullets and indentations). A wide variety of organizational signals can be used to indicate to students how a text is organized, and they might not all function in the same way (Schmid \& Baccino, 2002). Further studies on the role of organizational signals in note taking should try to manipulate other signals used to format the source document. Our findings also have to be nuanced on account of the participants' level of experience in reading 
and note taking. The participants in our study were relatively experienced, as they were college students. Less experienced individuals might respond differently to organizational signals. Further studies should investigate whether the formatting of the source document interacts with the note taking strategies used by students (e.g., non-generative strategies with verbatim copying or generative strategies with planning and concept mapping; Igo, Bruning, \& McCrudden, 2005). Finally, other studies on the working memory demands of note taking are needed to better understand the source of the cognitive effort related to note taking (e.g., Peverly, Vekaria, Reddington, Sumowski, Johnson, \& Ramsay, 2013). In particular, the role of visual spatial working memory in note taking should be further investigated, by examining how graphic organizers create different physical layouts of text that contribute to better note taking. 


\section{References}

Barbier, M.L., Piolat, A., Roussey, J.Y., \& Olive, T. (2006). Note-taking in second language: Language procedures and self-evaluation of the difficulties. Current Psychology Letters. Brain, Behavior and Cognition, 20, 3. Retrieved from http://cpl.revues.org/document1283.

Barbier, M.-L., Piolat, A., Roussey, J.-Y., \& Raby, F. (2008). Notetaking and writing from hypertexts in L1 and L2: cognitive effort and language procedures. International Journal of Applied Linguistics, 31-50.

Baker, L., \& Lombardi, B. R. (1985). Students' lecture notes and their relation to test performance. Teaching of Psychology, 12, 28-32.

Benton, S. L., Kiewra, K. A., Whitfill, J. M., \& Dennison, R. (1993). Encoding and externalstorage effects on writing processes. Journal of Educational Psychology, 85, 267-280.

DiCecco, V.M., \& Gleason, M.M. (2002). Using graphic organizers to attain relational knowledge from expository text. Journal of Learning Disabilities, 35, 306-321.

Gajria, M., Jitendra, A. K., Sood, S., \& Sacks, G. (2007). Improving comprehension of expository text in students with LD: A research synthesis. Journal of Learning Disabilities, 40, 210-225.

Haas, C. (1990). Composing in technological contexts: A study of note-making. Written Communication, 7(4), 512-547.

Haas, C., \& Hayes, J. R. (1986). 'What did I just say?' Reading problems in writing with the machine. Research in the Teaching of English, 22, 22-35.

Katayama, A. D., \& Robinson D. H. (2000). Getting students 'partially' involved in note taking using graphic organizers. Journal of Experimental Education, 68(2), 119-134. 
Kellogg, R.T., Whiteford, A. P., Turner, C. E., Cahill, M., \& Mertens, A. (2013) Working memory in written composition: An evaluation of the 1996 model. Journal of Writing Research, 5(2), 159-190.

King, A. (1992). Comparison of self-questioning, summarizing, and note taking-review as strategies for learning from lectures. American Educational Research Journal, 29(2), 303-323.

Kobayashi, K. (2005). What limits the encoding effect of note taking? A meta-analytic examination. Contemporary Educational Psychology, 30, 242-262.

Kobayashi, K. (2006). Combined effects of note taking/-reviewing on learning and the enhancement through interventions: A meta-analytic review. Educational Psychology, $26(3), 459-477$.

Igo, L. B., Bruning, R., \& McCrudden, M. T. (2005). Exploring differences in students' copyand-paste decision making and processing: A mixed-methods study. Journal of Educational Psychology, 97, 103-116.

Landauer, T. K., Foltz, P. W., \& Laham, D. (1998). Introduction to Latent Semantic Analysis. Discourse Processes, 25, 259-284

Lemarié, J., Lorch, R. F., Eyrolle, H., \& Virbel, J. (2008). SARA: A Text-Based and ReaderBased Theory of Signaling. Educational Psychologist, 43, 27-48,

Lorch, R. F., \& Lorch, E. P. (1995). Effects of organizational signals on text-processing. Journal of Educational Psychology, 87(4), 537-544.

Mayer, R. E. (1996). Learning strategies for making sense out of expository text: The SOI model for guiding three cognitive processes in knowledge construction. Educational Psychology Review, 8, 357-371. 
Meyer, B. J. F. (1985). Signaling the structure of text. In D. H. Jonassen (Ed.), The technology of text (pp. 64-89). Englewood Cliffs, NJ: Educational Technology.

Meyer, B. J. F., \& Poon, L. W. (2001). Effects of structure strategy training and signaling on recall of text. Journal of Educational Psychology, 93, 141-159.

Mueller, P. A., \& Oppenheimer, D. M. (2014). The Pen Is Mightier Than the Keyboard: Advantages of Longhand Over Laptop Note Taking. Psychological Science, 25(6), 1159-1168.

Nye, P. A., Crooks, T. J., Powley, M., \& Tripp, G. (1984). Student note taking related to university examination performance. Higher Education, 13, 85-97.

Olive, T. (2004). Working memory in writing: Empirical evidences from the dual-task technique. European Psychologist, 9, 32-42.

Olive, T. (2012). Writing and working memory: A summary of theories and of findings. In E. Grigorenko, E. Mambrino, \& D. Preiss (Eds.), Handbook of Writing: A mosaic of new perspectives. New York: Psychology Press.

Olive, T. (2014). Toward an Incremental and Cascading Model of Writing: A review of research on writing processes coordination. Journal of Writing Research, 6, 173-194.

Olive, T., Kellogg, R. T., \& Piolat, A. (2002). Studying text production with the triple task technique: Why and how? In T. Olive \& C. M. Levy (Eds.), Contemporary tools and techniques for studying writing (pp. 31-58). Dordrecht: Kluwer Academic Press.

Olive, T. \& Passerault, J.-M. (2012). The visuospatial dimension of writing. Written Communication, 29, 326-344.

Peverly, S. T., Vekaria, P. C., Reddington, L. A., Sumowski, J. F., Johnson, K. R., \& Ramsay, C. M. (2013). The Relationship of Handwriting Speed, Working Memory, Language 
Processing time and cognitive effort of longhand note taking 26

Comprehension and Outlines to Lecture Note-taking and Test-taking among College Students. Applied Cognitive Psychology, 27, 115-126.

Piolat, A., Olive, T., \& Kellogg R. T. (2005). Cognitive effort of note taking. Applied Cognitive Psychology, 18, 1-22.

Piolat, A., Olive, T., Roussey, J. Y., Thunin, O., \& Ziegler, J. C. (1999). ScriptKell: A computer assisted tool for measuring the distribution of time and cognitive effort in writing and other complex cognitive activities. Behavior Research Methods, Instruments, \& Computers, 31, 113-121.

Robinson, D. H., \& Kiewra, K. A. (1995). Visual argument: Graphic organizers are superior to outlines in improving learning from text. Journal of Educational Psychology, 87(3), 455-467.

Robinson, D. H., Katayama, A. D., Dubois, N. F., \& Devaney, T. (1998). Interactive effects of graphic organizers and delayed review in concept acquisition. Journal of Experimental Education, 67, 17-31.

Schmid, S., \& Baccino, T. (2002). Perspective shift and text format: An eye-tracking study. Current Psychology Letters, Behaviour, Brain \& Cognition, 9, 73-87.

Schriver, K. (1996). Dynamics in document design. New York: John Wiley \& Sons.

Titsworth, B. S. (2001). The effects of teacher immediacy, use of organizational lecture cues, and students' note taking on cognitive learning. Communication Education, 50(4), 283297.

Williams, R. L., \& Eggert, A. (2002). Note taking predictors of test performance. Teaching of Psychology, 29(3), 234-237. 


\section{Appendix 1: Formatted and unformatted source text}

\section{Unformatted source text}

Le réseau Sunbus ne cesse de progresser et de s'informatiser, mais cette évolution entraîne de nombreuses incompréhensions pour les usagers. Le document qui suit essaie de faire une mise au point sur l'utilisation des titres de transport, à travers un guide et ces sept recommandations ou préconisations. Précisons que les abonnements mensuels peuvent être rechargés à compter du 22 de chaque mois. Trois astuces sont à connaître pour l'utilisation des titres de transport. A chaque validation, l'écran affiche le contenu de votre Suncarte, c'est-à-dire le solde qu'il vous reste. A chaque rechargement, vous pouvez obtenir un décompte de vos droits, c'est-à-dire le type d'abonnement que vous avez souscrit, la durée de votre abonnement, le solde de la Suncarte, etc. Après avoir validé votre voyage, vous pouvez représenter votre carte au valideur pour en connaître le contenu, sans que celui-ci ne vous débite de voyage supplémentaire. Les règles de correspondance entre bus sont définies comme suit. La correspondance est autorisée pendant 59 minutes entre 2 bus de lignes différentes dont l'itinéraire est complémentaire. Elle ne peut, en aucun cas, constituer un aller/retour. Toutefois une deuxième correspondance est autorisée sur les lignes en périphérie qui constituent un prolongement de la précédente. Sachez que tout titre magnétique plié ou détérioré ne pourra être échangé. La fonction des différents voyants de l'écran valideur est la suivante. Quand le voyant est vert, votre voyage est enregistré, vous êtes en règle. Vous pouvez maintenant profiter de la densité de notre réseau en fonction de vos besoins de déplacement. Quand le voyant est rouge, votre titre de transport n'est pas valable. Veuillez lire le motif du refus sur l'écran et si besoin, achetez un titre au conducteur. Et enfin quand aucun voyant ne s'allume, il faut représenter votre carte devant l'autre valideur. Et si celui-ci est toujours muet, vous devez vous acquitter d'un titre auprès du conducteur et vous rendre dans les meilleurs délais à une de nos Sunboutiques pour régulariser votre situation (avec la Suncarte et le titre acheté à bord qui vous sera échangé). En cas d'infraction, les pénalités dues à la police des transports peuvent être résumées comme suit. En cas de titre de transport non valide ou de non validation, vous êtes passible d'une amende de $24 €$, majorée de $30 €$ de frais de dossier pour un paiement différé. En cas de voyage sans titre de transport ou de toutes autres infractions à la police des transports, vous êtes passible d'une amende de $36 €$, majorée de $30 €$ de frais de dossier pour un paiement différé. Les différents aspects fonctionnels de la Suncarte sont les suivants. Vos droits sont valables un an, à partir de la date de création et, bien entendu, il ne faut pas oublier de la valider à chaque montée dans le bus même en cas de correspondance, présentez votre Suncarte à $2 \mathrm{~cm}$ du valideur, sans l'agiter. Le défaut de validation vous expose à une amende. Votre Suncarte contient votre numéro de carte, sa date de création, votre Nom et Prénom ainsi que votre photo d'identité. Votre Suncarte est strictement personnelle. En ce qui concerne le chargement de votre carte, vous pouvez charger un abonnement, un forfait, un contrat ou des voyages unitaires. Les deux titres peuvent être chargés simultanément. Le valideur débite par priorité l'abonnement valable. Le renouvellement de votre Suncarte doit être effectué un an après la date anniversaire de sa création (imprimé au dos de votre carte), et vous devez vous rendre aux Sunboutiques pour prolonger vos droits. En cas de perte, de vol ou de détérioration, déclarez-le rapidement à votre Sunboutique qui établira une nouvelle Suncarte (les frais d'établissement de carte sont de $7.60 €$ ). Les frais d'établissement et les frais forfaitaires seront à votre charge pour la création de votre nouvelle carte et votre ancienne carte ne sera plus utilisable. Pour votre confort d'utilisation et pour ne pas abîmer votre Suncarte, un étui rigide vous est offert. Veillez à la laisser dans l'étui y compris pour les validations.

\section{Formatted source text}

Le réseau Sunbus ne cesse de progresser et de s'informatiser, mais cette évolution entraîne de nombreuses incompréhensions pour les usagers. Le document qui suit essaie de faire une mise au point sur l'utilisation des titres de transport, à travers un guide et ces sept recommandations ou préconisations.

- Précisons que les abonnements mensuels peuvent être rechargés à compter du 22 de chaque mois.

- Trois astuces sont à connaître pour l'utilisation des titres de transport.

- A chaque validation, l'écran affiche le contenu de votre Suncarte, c'est-à-dire le solde qu'il vous reste.

- A chaque rechargement, vous pouvez obtenir un décompte de vos droits, c'est-à-dire le type d'abonnement que vous avez souscrit, la durée de votre abonnement, le solde de la Suncarte, etc. 
- Après avoir validé votre voyage, vous pouvez représenter votre carte au valideur pour en connaître le contenu, sans que celui-ci ne vous débite de voyage supplémentaire.

- Les règles de correspondance entre bus sont définies comme suit.

- La correspondance est autorisée pendant 59 minutes entre 2 bus de lignes différentes dont l'itinéraire est complémentaire.

- Elle ne peut, en aucun cas, constituer un aller/retour. Toutefois une deuxième correspondance est autorisée sur les lignes en périphérie qui constituent un prolongement de la précédente.

- Sachez que tout titre magnétique plié ou détérioré ne pourra être échangé.

- La fonction des différents voyants de l'écran valideur est la suivante.

$\circ$ Quand le voyant est vert, votre voyage est enregistré, vous êtes en règle. Vous pouvez maintenant profiter de la densité de notre réseau en fonction de vos besoins de déplacement.

- Quand le voyant est rouge, votre titre de transport n'est pas valable. Veuillez lire le motif du refus sur l'écran et si besoin, achetez un titre au conducteur.

- Et enfin quand aucun voyant ne s'allume, il faut représenter votre carte devant l'autre valideur. Et si celui-ci est toujours muet, vous devez vous acquitter d'un titre auprès du conducteur et vous rendre dans les meilleurs délais à une de nos Sunboutiques pour régulariser votre situation (avec la Suncarte et le titre acheté à bord qui vous sera échangé).

- En cas d'infraction, les pénalités dues à la police des transports peuvent être résumées comme suit.

- En cas de titre de transport non valide ou de non validation, vous êtes passible d'une amende de $24 €$, majorée de $30 €$ de frais de dossier pour un paiement différé.

- En cas de voyage sans titre de transport ou de toutes autres infractions à la police des transports, vous êtes passible d'une amende de $36 €$, majorée de $30 €$ de frais de dossier pour un paiement différé.

- Les différents aspects fonctionnels de la Suncarte sont les suivants.

- Vos droits sont valables un an, à partir de la date de création et, bien entendu, il ne faut pas oublier de la valider à chaque montée dans le bus même en cas de correspondance, présentez votre Suncarte à $2 \mathrm{~cm}$ du valideur, sans l'agiter. Le défaut de validation vous expose à une amende.

- Votre Suncarte contient votre numéro de carte, sa date de création, votre Nom et Prénom ainsi que votre photo d'identité. Votre Suncarte est strictement personnelle.

- En ce qui concerne le chargement de votre carte, vous pouvez charger un abonnement, un forfait, un contrat ou des voyages unitaires. Les deux titres peuvent être chargés simultanément. Le valideur débite par priorité l'abonnement valable.

- Le renouvellement de votre Suncarte doit être effectué un an après la date anniversaire de sa création (imprimé au dos de votre carte), et vous devez vous rendre aux Sunboutiques pour prolonger vos droits.

- En cas de perte, de vol ou de détérioration, déclarez-le rapidement à votre Sunboutique qui établira une nouvelle Suncarte (les frais d'établissement de carte sont de $7.60 €$ ). Les frais d'établissement et les frais forfaitaires seront à votre charge pour la création de votre nouvelle carte et votre ancienne carte ne sera plus utilisable.

- Pour votre confort d'utilisation et pour ne pas abîmer votre Suncarte, un étui rigide vous est offert. Veillez à la laisser dans l'étui y compris pour les validations. 
Table 1

Number of ideas in the notes and in the summaries when the source document was either formatted or unformatted. Standard deviations are shown in parentheses.

\section{Text}

Unformatted Formatted

Number of ideas in notes

$17.4(3.3)$

$20.4(2.9) * * *$

Number of ideas in summaries

$13.8(3.4)$

$12.8(3.1)$

Number of suppressed ideas

$-3.6$

$-7.6 * * *$

NB: Maximum number of ideas is 23. ***: $p<.001$. 


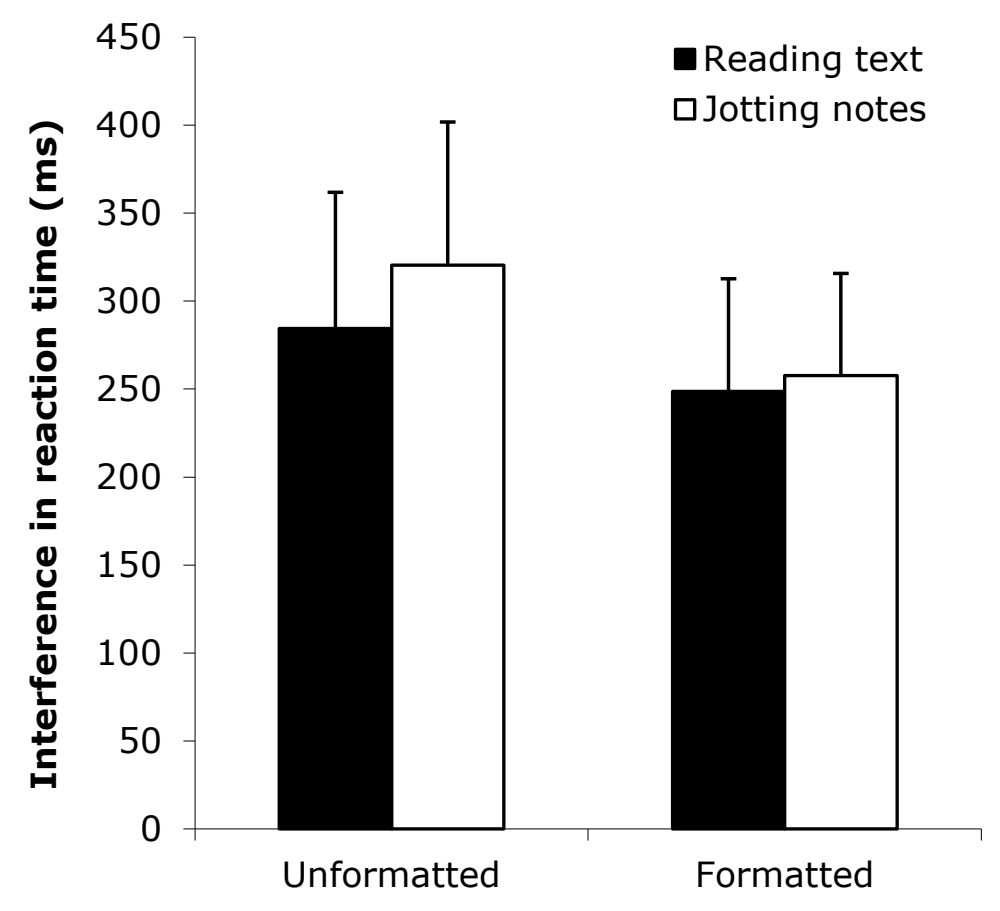

Figure 1. Participants' cognitive effort (as measured by mean secondary task reaction times) when reading or noting ideas in the formatted or unformatted source texts. Error bars represent standard deviations. 


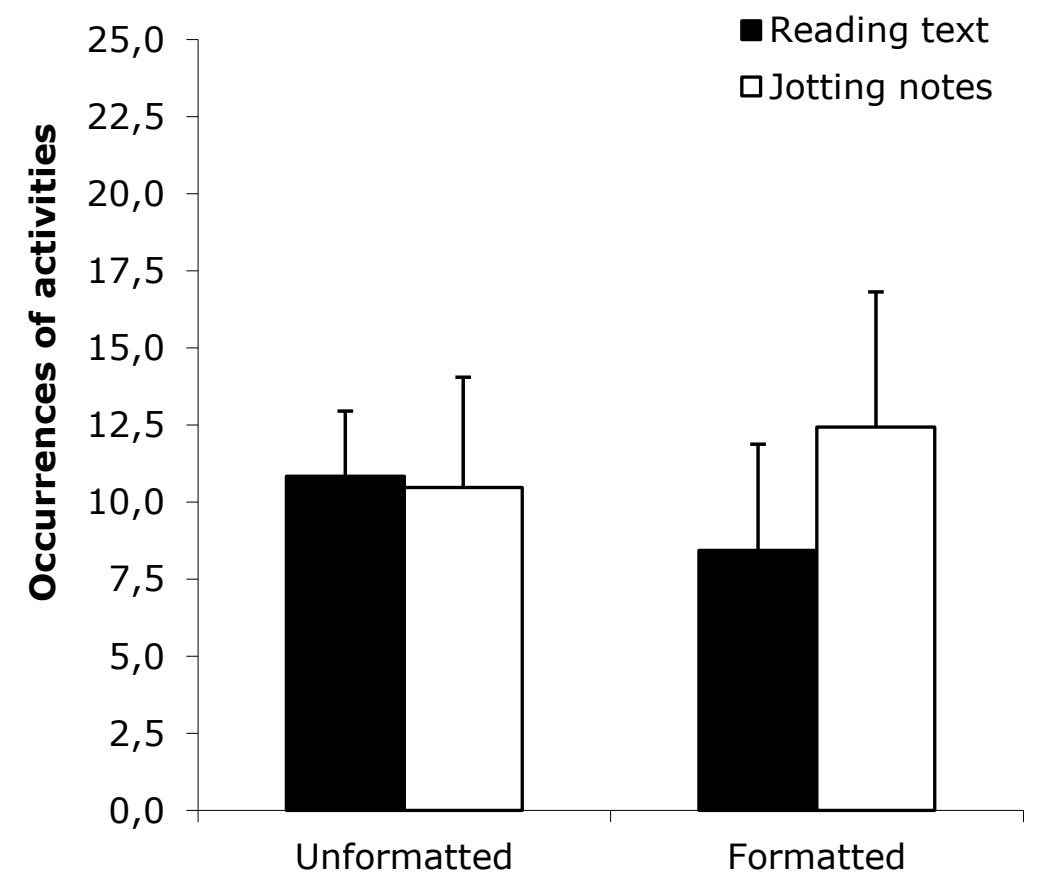

Figure 2. Occurrences of source-reading and idea-noting activities for the formatted and unformatted source texts. Error bars represent standard deviations. 


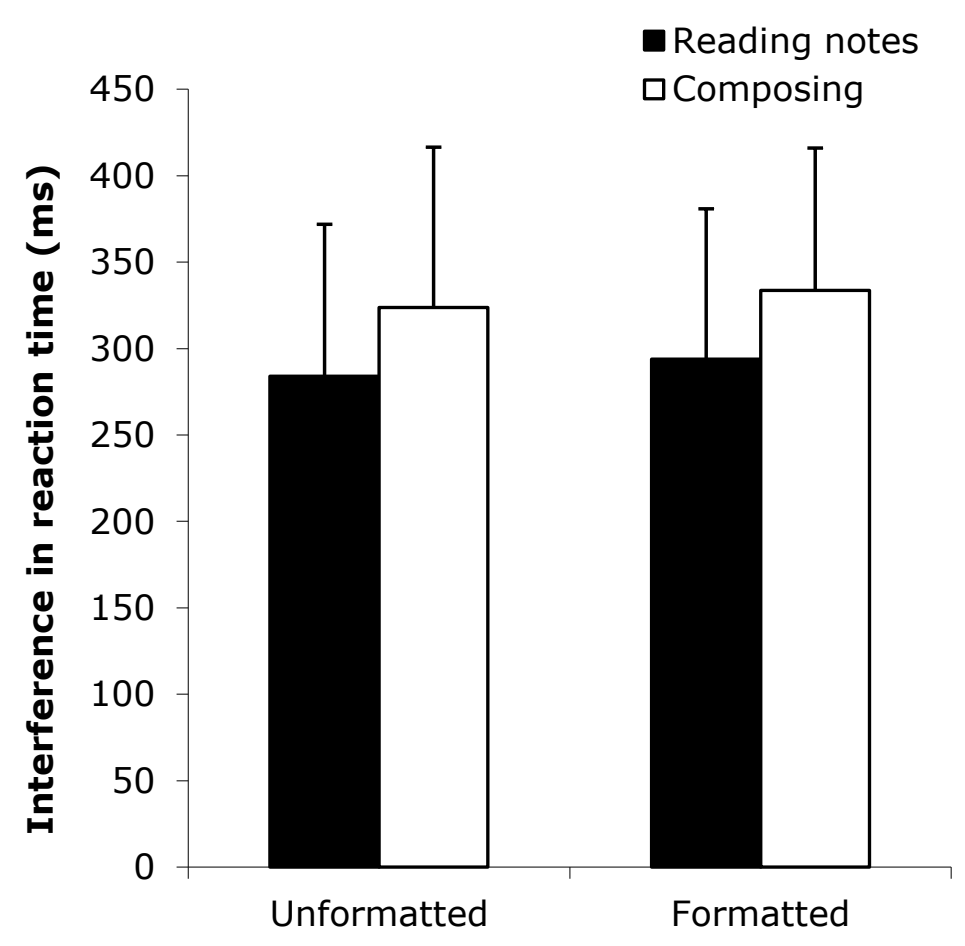

Figure 3. Participants' cognitive effort (as measured by mean interference reaction times) when reading their notes or composing their summaries based on the formatted or unformatted source texts. Error bars represent standard deviations. 


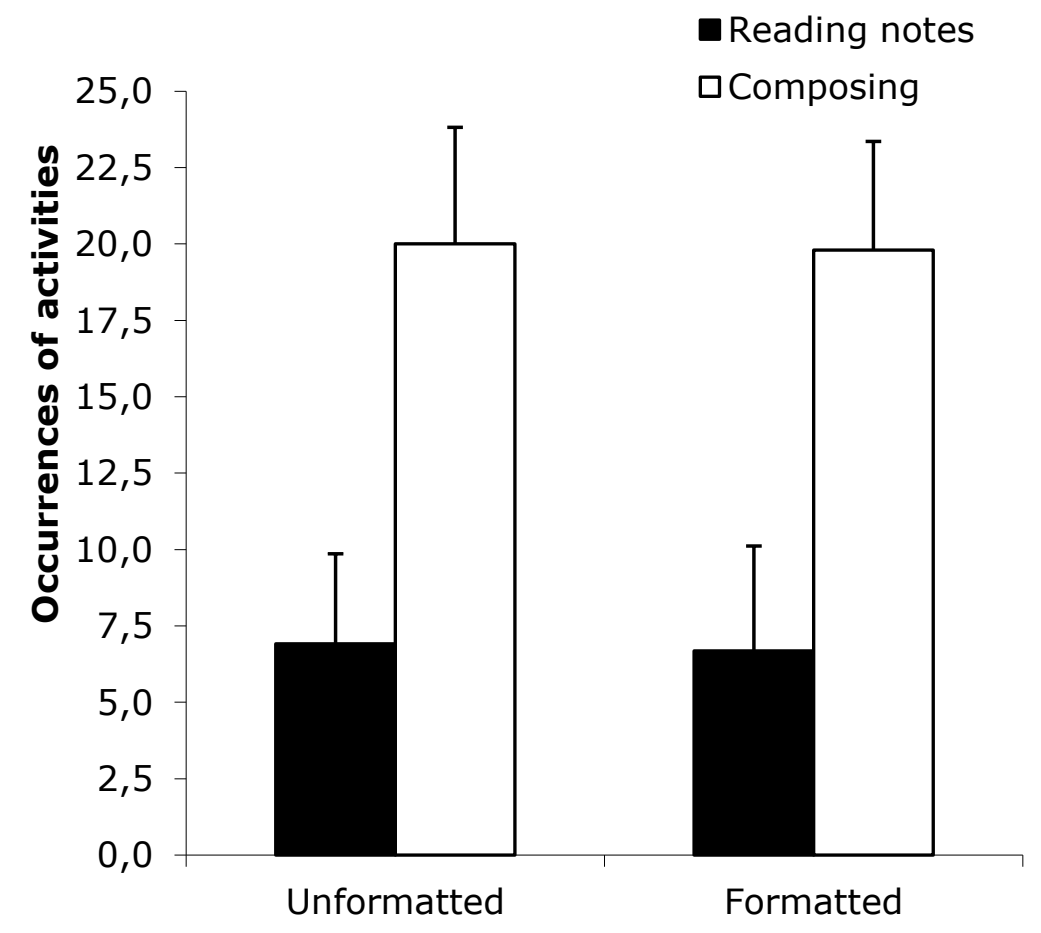

Figure 4. Occurrences of note-reading and composition activities for the formatted and unformatted source texts. Error bars represent standard deviations. 